\title{
Eco-economic mechanism of formation of the system of national priorities in the conditions of sustainable development
}

\author{
Maryna Kovbatiuk ${ }^{1, *}$, Vladyslava Shevchuk ${ }^{1}$, Viktoriya Shklyar ${ }^{1}$, Ivanna Strilok $^{1}$, \\ and George Kovbatiuk ${ }^{1}$ \\ ${ }^{1}$ State University Of Infrastructure And Technologies, Department of Theoretical and Applied \\ Economics, 9, Kyrylivska St., 04071 Kyiv, Ukraine
}

\begin{abstract}
In the article the authors have developed an eco-economic mechanism for the formation of a system of national priorities in terms of sustainable development. The mechanism is based on the Concept of Sustainable Development, which improves its theoretical basis: characteristics, principles and components. Their manifestation at the world and national level is taken into account. Diagnosis of the state of the countries is carried out The EU-27 as whole and individual countries, namely Germany, Lithuania, Latvia, Poland, Romania, Estonia, Bulgaria, Slovakia and Ukraine in terms of sustainable development in terms of three key areas - economic, social and environmental. Analytical study of trends in indicators for 10 years for the European Union and Ukraine has led to the conclusion that the application of sustainable development strategy leads to positive results. Based on the concept of sustainable development, a set of defined environmental imperatives and the Strategy for Sustainable Development of Ukraine until 2030, the authors formed a system of national strategic priorities.
\end{abstract}

\section{Introduction}

The fundamental methodological basis for the formation of a country's economic development strategy is an economic model, the main provisions of which are concretized and approved by national legislation. It ensures the implementation of specific measures in the economic policy of the state to achieve a set of national goals at a certain specific historical stage.

Economic development is based on economic growth. Economic growth rates characterize the current state of the economy, give an idea of the future prospects of its development, sources and external effects of growth.

In the classical version, economic growth ensures stable rates of development over a long period. However, simple economic growth is largely based on the extraction and use of non-renewable natural resources, the gradual depletion of which creates risks for the stability of growth.

\footnotetext{
* Corresponding author: mvkov58@gmail.com
} 
In this regard, the modern conditions of development require such economic growth, the implementation of which is not associated with a negative impact on the environment, accompanied by the creation of favorable conditions for improving the quality of life and ensuring equality of opportunities for all groups of the population of the country. This strategy has found its reflection in the concept of sustainable development.

The implementation of this concept in each individual country requires the development of a set of imperatives, which are specifically reflected in the system of national priorities at a specific historical stage of its development.

In the modern scientific literature, certain studies of theoretical, methodological and analytical nature on sustainable development are carried out, but they concern either certain elements of infrastructure, or certain sectors of the economy, or certain ways of transition to sustainable development. For example, in article [1] offer a methodological approach to assessing the prospects of the Baikal region, in particular identify future trends in ecosocio-economic development of Baikal region on the basis of a green economy and offer a mechanism to regulate the formation of a green economy in the Baikal region.

The calculation of regional efficiency of ecological innovations, which are the main driver of the coordinated development of resource, ecological and economic systems, is carried out in their research by Chinese scientists [2]. They argue that in order to achieve sustainable economic growth, it is necessary to form a differentiated policy of agglomeration at different stages and regions and to strengthen the driving mechanism of eco-innovation.

Michał Dudek and Wioletta Wrzaszcz [3] investigate such an integral part of the concept of sustainable development as eco-innovation in agriculture.

Analysis of existing views and research indicates a lack of approaches to the formation of a system of goals and priorities for sustainable development at the national level, taking into account environmental imperatives. This creates the need for the development of theoretical and methodological foundations for the formation of a system of national priorities based on environmental imperatives.

\section{Material and methods}

The purpose of this article is to develop an eco-economic mechanism for the formation of a system of national priorities based on environmental imperatives in the context of sustainable development. To achieve this goal on the basis of a systematic approach used methods of scientific abstraction, logical generalization and systematization for theoretical justification of the set of components of the concept of sustainable development, retrospective, comparative and systematic analysis and graphical presentation of data to assess indicators of sustainable development. The information base of the study is legislative and regulatory documents of national and international levels, statistical information of the State Statistics Service of Ukraine, UNCTADstat and Eurostat, scientific publications and the results of personal research of the authors.

\section{Results and discussions}

Sustainable development expresses a fairly simple idea: achieving harmony between people, between society and nature, resolving the contradictions that exist in our time, the contradictions between nature and society, between ecology and economy, between developed countries and those developing, between rich and poor, between already formed needs of people and reasonable needs, between present and future generations, etc. [4]. 
Therefore, the concept of sustainable development, which contains three mandatory components - economic growth, social progress and environmental protection, is the basis of the eco-economic mechanism of formation of the system of national priorities proposed by the authors (Fig. 1).

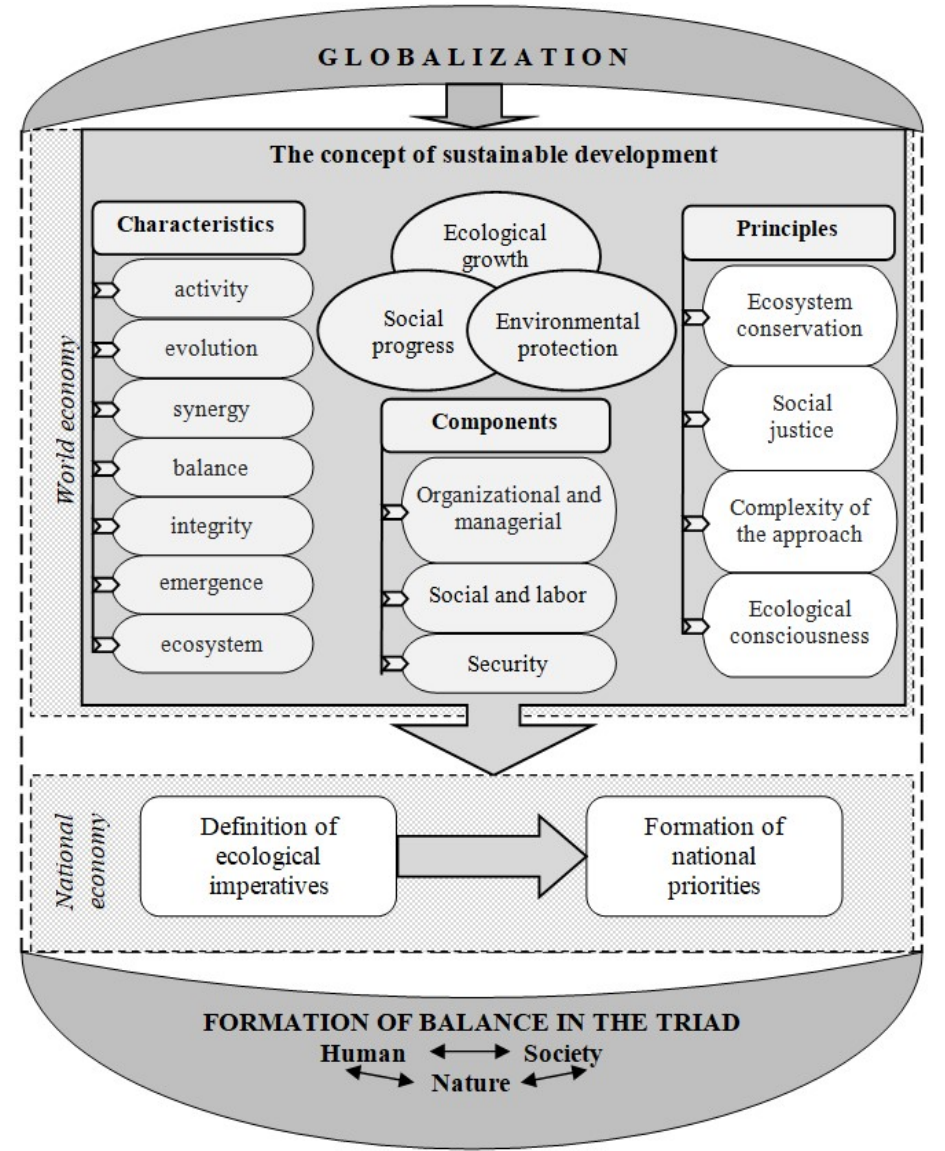

Fig. 1. Eco-economic mechanism of formation of the system of national priorities in the conditions of sustainable development.

Source: developed by the authors

The concept of sustainable development has its own characteristics, contains organizational components and is based on certain principles.

The components determine the structure and understanding of the sustainable development model. These include the following:

- organizational and managerial component - includes public administration and regulation of sustainable development (provides a legal basis in the form of laws and other regulations through governmental and non-governmental organizations on sustainable development, as well as provides communication with society through non-governmental organizations concerned various aspects of sustainable development); market stimulation and regulation (contributes to the rationalization of economic behavior of individuals), the system of corporate governance (in accordance with the standards of corporate governance (approved by the OECD - Organization for Economic Cooperation and Development); 
- social and labor component - includes socialization (formation of a sense of common purpose) and social interaction, social responsibility of man, enterprise, society, state (compliance with social norms, recognition of the obligation to accept their responsibilities);

- security component - includes: economic security (macroeconomic, investment, innovation, intellectual values, financial, foreign economic), social security (level, quality of life, spiritual and cultural life), environmental security (air, land resources, forests, water resources, waste management), energy, information, legal, military security [5].

Based on document analysis: UN Declaration on Environment and Development [6], International Earth Charter Declaration [7], Declarative document "World Charter of Nature" [8], Decree of the President of Ukraine "On the goals of sustainable development of Ukraine for the period up to 2030" [9], in the Strategy of Sustainable Development of Ukraine until 2023 (draft-2017) [10] generalized principles of the model of sustainable development were defined, which include:

- preservation of ecosystems (maintenance of the natural balance of ecosystems is of paramount importance for nature and fundamental to the healthy life of society (food resources, natural recreation areas). The damage done to ecosystems today is largely the result of economic enrichment, and their destruction in the long run will harm the world economy;

- social justice (as the basis of socio-economic development of the national economy and the world economy as a whole, provides security and legal guarantees of societies, environmental protection. The UN promotes social justice as an important prerequisite for the transition of world society to sustainable development);

- comprehensive approach to solving problems (interconnectedness of solving social, economic and environmental global problems, integration of economic, social and environmental policies at all levels of government, for the transition of world society to sustainable development);

- environmental awareness (raising public environmental awareness, responsibility, development of environmental knowledge, thinking; support for environmental organizations and increase their influence in the international arena).

The main characteristics of the sustainable development model are: activity (replacement of existing system parameters); evolutionary (gradual characteristic changes); synergetic (coexistence of synergetic different levels: society, micro, meso, macro, mega with a tempting nonlinear dependence on losses and benefits); balance (balance of development in space and time of hierarchical levels of the economy to eliminate structural imbalances and social, environmental, economic contradictions) [4]; integrity / equivalence of all elements (all components of the social system are significant); emergence (abrupt dynamics of functioning processes) [11]; ecosystems, which consists in the management of ecosystems (natural resources) to ensure the rational use of nature, the integration of international and national environmental programs (methods). Ecosystems are ecologically important (regulate and influence the climate, natural disasters, water balance quality, recreational resources, soil formation processes) and economically important for humanity (food, water, raw materials, wood).

The considered components of the concept of sustainable development are necessary for any country, so they are considered at the level of the world economy. The peculiarities of the development of a separate national economy are reflected in the system of national priorities, which are formed on the basis of certain environmental imperatives.

Diagnosis of the state of individual countries in terms of sustainable development should be considered in terms of three key areas - economic, social and environmental. In accordance with the identified areas, an analytical study of trends in indicators over a tenyear period for individual countries of the European Union and Ukraine. 
Among the EU member states, Germany was chosen as a country with a high level of development and Ukraine's neighbors of the first and second order, namely Lithuania, Latvia, Poland, Romania, Estonia, Bulgaria, Slovakia.

The analysis of the economic direction is carried out on the basis of indicators of the value of real GDP per capita, employment rate, R\&D expenditures and the value of gross debt of the general government sector (Fig. 2).
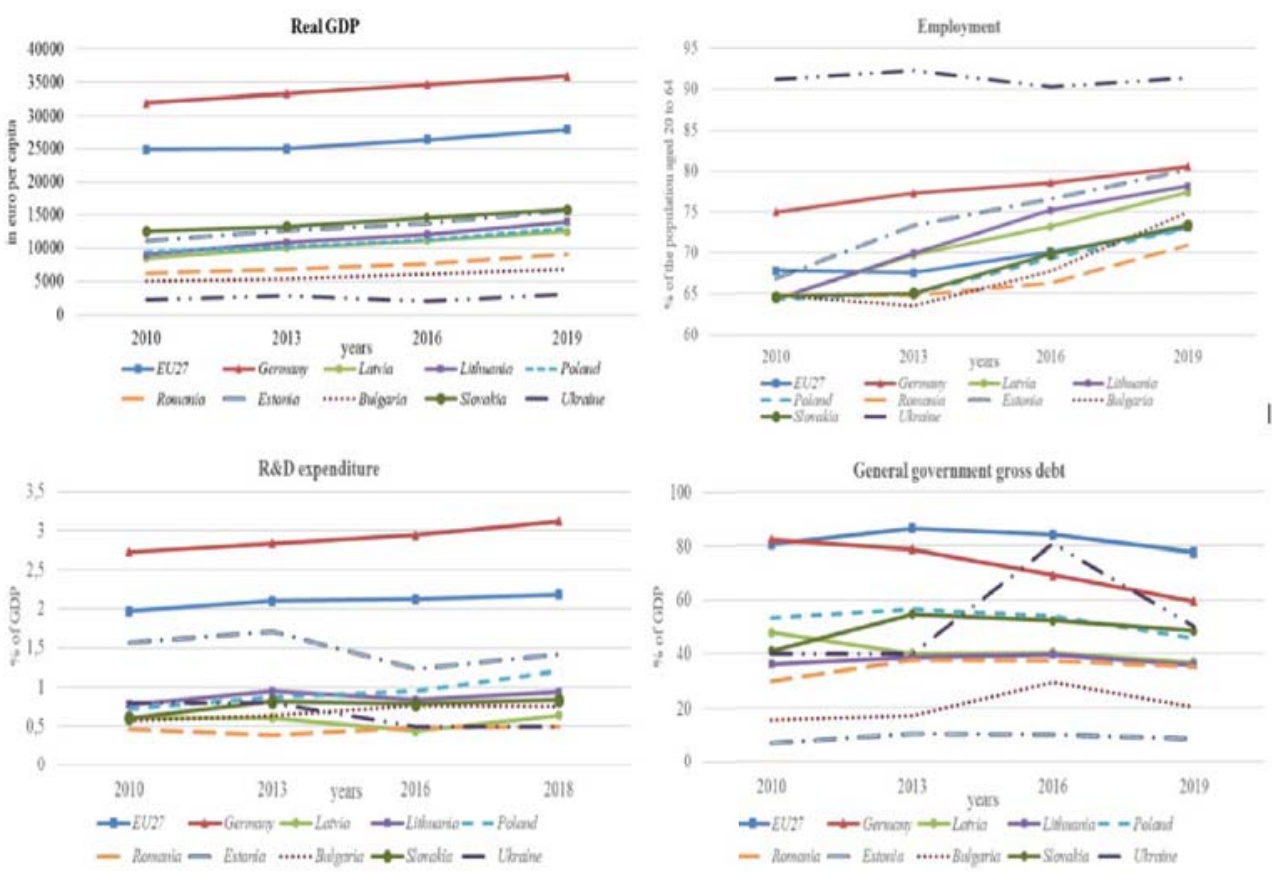

Fig. 2. Dynamics of change of indicators of economic group of separate countries of the European Union.

Source: formed by the authors on the basis $[12,13]$

The increase in the level of real GDP per capita is typical for all analyzed countries during 2010-2019. The largest growth over the ten-year period is Lithuania $(+54.8 \%)$, Latvia and Romania - almost $47 \%$, the European average coincides with the growth rate of Germany $-12 \%$ [12]. In Ukraine, as of 2019 , this indicator increased by $39.3 \%$ compared to 2010. This trend is positive, despite the much lower real GDP per capita compared to EU countries and its significant decline in 2015-2016.

The employment rate indicates a stable, albeit insignificant, annual growth for all analyzed countries. The most significant growth is observed in Lithuania $(+21.6 \%)$, Latvia $(+20.4 \%)$, Estonia $(+20 \%)$ and Bulgaria $(+15.9 \%)$. The employment rate in Ukraine was calculated in relation to the number of economically active population during the analyzed period, so it has slightly higher values, which range from 90.1 to $91.8 \%$.

R\&D expenditures account for a small share of GDP, ranging from $0.5 \%$ (Ukraine, Romania) to 3\% (Germany). The decrease in R\&D funding in 2019 compared to 2010 is typical for Estonia (-10.2\%) and Ukraine (-37.5\%).

The increase in the gross debt of the general government sector is observed in five of the studied countries - Bulgaria $(+31.2 \%)$, Estonia $(+27.3 \%)$, Ukraine $(+26 \%)$, Romania $(+19.3 \%)$, Slovakia $(+18.3 \%)$. The average value of gross debt in the EU decreased in 2019 by $3.6 \%$ compared to 2010 . 
Social risk indicators include the risk of poverty, the ratio of income between the richest and the poorest, mortality from tuberculosis, AIDS and hepatitis, education, life expectancy at birth, the proportion of the population at risk of poverty or social exclusion, the employment rate of graduates.

Given the differences in the calculations of the social group, Ukraine was analyzed on three indicators out of six. In general, the group of social indicators has undergone the greatest positive changes (Fig. 3).
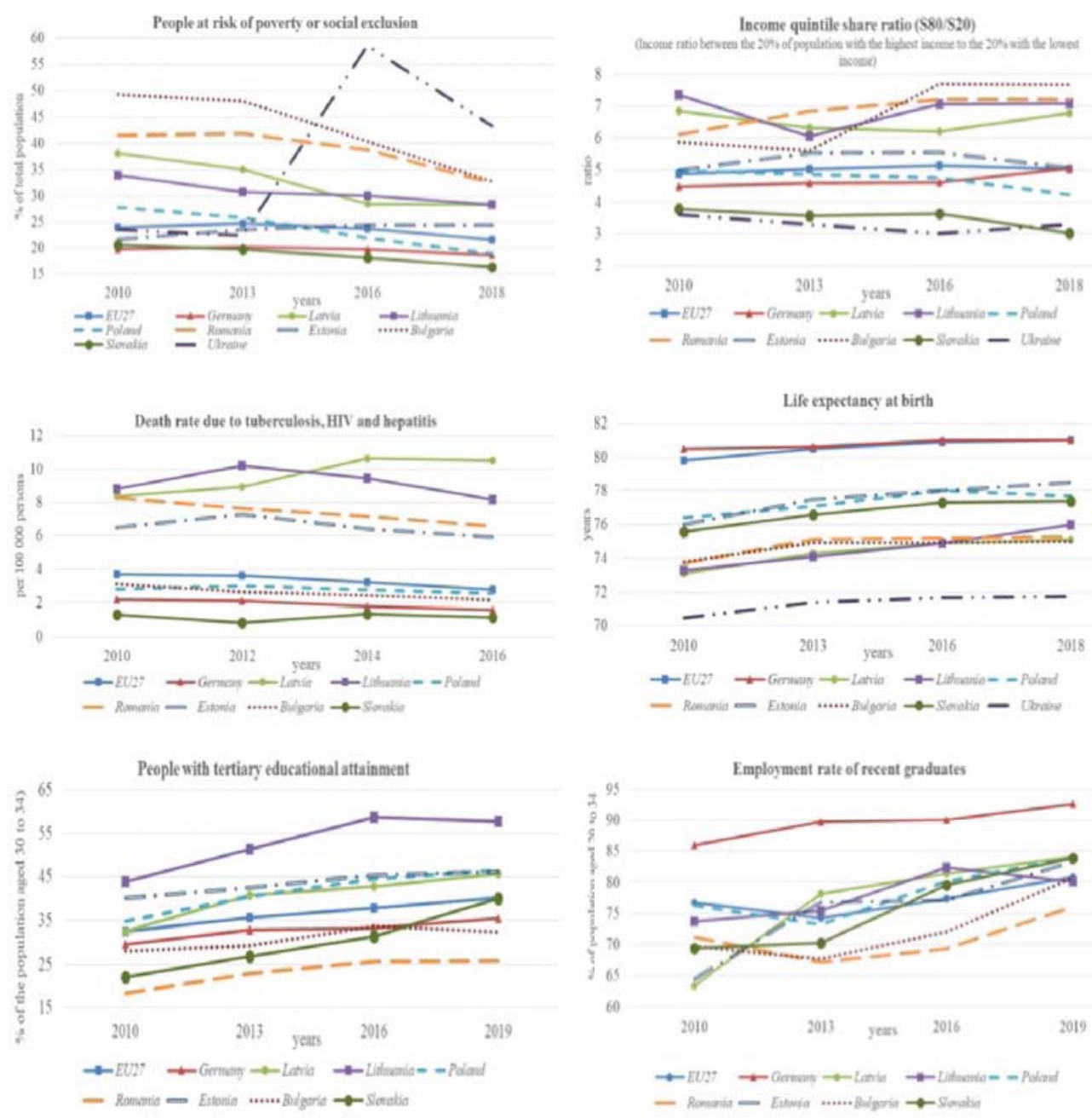

Fig. 3. Dynamics of change of indicators of social group of separate countries of the European Union.

Source: formed by the authors on the basis $[12,14,15]$

The risk of poverty has a declining trend for most countries. Estonia and Ukraine marked an increase in this index by $12 \%$ and $83.8 \%$, respectively. This indicator underwent a significant jump in Ukraine in 2015-2016, which is a consequence of the annexation of part of the Ukrainian territory and the conduct of hostilities. The last two years, this figure is characterized by a gradual decline.

The ratio of income between the most and the least well-off population fluctuates slightly during the analyzed period. The increase in the index for the EU countries was only 
$3.3 \%$ in 2019 compared to 2010 . The largest growth is typical for Bulgaria $(+30.7 \%)$, Romania (+18\%) and Germany (+12.9\%).

Mortality from tuberculosis, AIDS and hepatitis tends to decrease, ranging from $7 \%$ to $30 \%$. The exception is Latvia, where there was an increase of $25.5 \%$ in 2019 compared to 2010. Life expectancy at birth is characterized by an annual increase of $1-3 \%$ for all countries. The education of the population also has a positive annual dynamics for the studied countries. Slovakia $(+81.4 \%)$ had a special growth in 2019 , and Estonia the lowest $(+14.9 \%)$ compared to 2010 . The level of employment of recent graduates for the period 2010-2019 increased the most in Latvia $(+32.6 \%)$, Estonia $(+29.1 \%)$ and Bulgaria $(+15.8 \%)$. The average European growth is $5.3 \%$.

Considerable attention among indicators of sustainable development is paid by countries in the ecological direction carried out according to the indicators: the share of renewable energy, the share of renewable energy sources in transport, greenhouse gas emissions and CO2 emissions from new cars (Fig. 4).
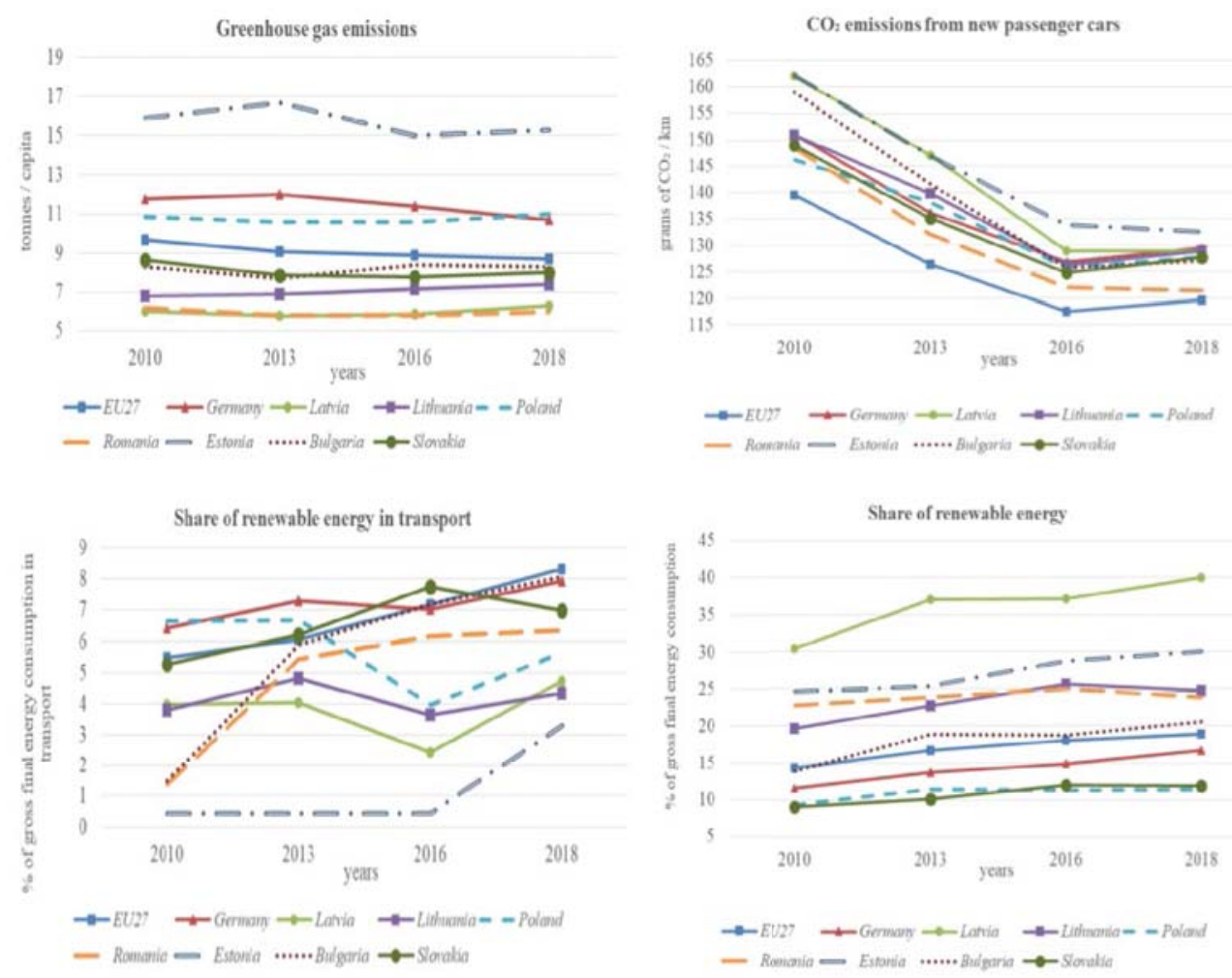

Fig. 4. Dynamics of change of indicators of ecological group of separate countries of the European Union.

Source: formed by the authors on the basis [12]

Growing positive trends are characteristic of the total share of renewable energy and the growing use of renewable energy sources in transport. The growth of the first indicator for the ten-year period for the EU countries is $31.1 \%$, and the second $-51.1 \%$. The most significant jump in the share of renewable energy was made by Bulgaria $-47.8 \%$ and Germany $-42.9 \%$. As for the share of renewable energy sources in transport, in 2019 Estonia increased its use by 7.5 times, Bulgaria by 5 times, Romania by 4.5 times compared 
to 2010 . However, for Poland since 2014 is characterized by the opposite the trend that led to a decrease in this index by $15 \%$ in 2019.

Greenhouse gas and $\mathrm{CO} 2$ emissions from new cars are accompanied by an annual reduction. This situation indicates increased attention to the environmental component and concern about the state of the environment by all countries.

Thus, the analysis shows that the application of the strategy of sustainable development leads to positive results and balance in the triad: human - society - nature.

Given the positive trends identified on the basis of diagnostics of sustainable development in different countries, we can identify the main environmental imperatives and formulate development priorities for the economy of Ukraine. The ecological imperative is a requirement for the people (economic entities) of the country and the world to limit and stop the economic activity that is harmful to nature and to take into account the anthropogenic pressure on the environment. Environmental imperatives are manifested in compliance with all existing and future (they are dynamic and may change over time, society and globalization) environmental rules, regulations, restrictions and prohibitions.

Y. Shpilova and M. Ilyina [16]note that environmental imperatives develop in a spiral they operate in a certain area, over a period of time, under certain technological, economic conditions and circumstances, and then change, improve or transform, resulting in a higher and more environmentally oriented level.

The set of current environmental imperatives for Ukraine is presented at Fig. 5.

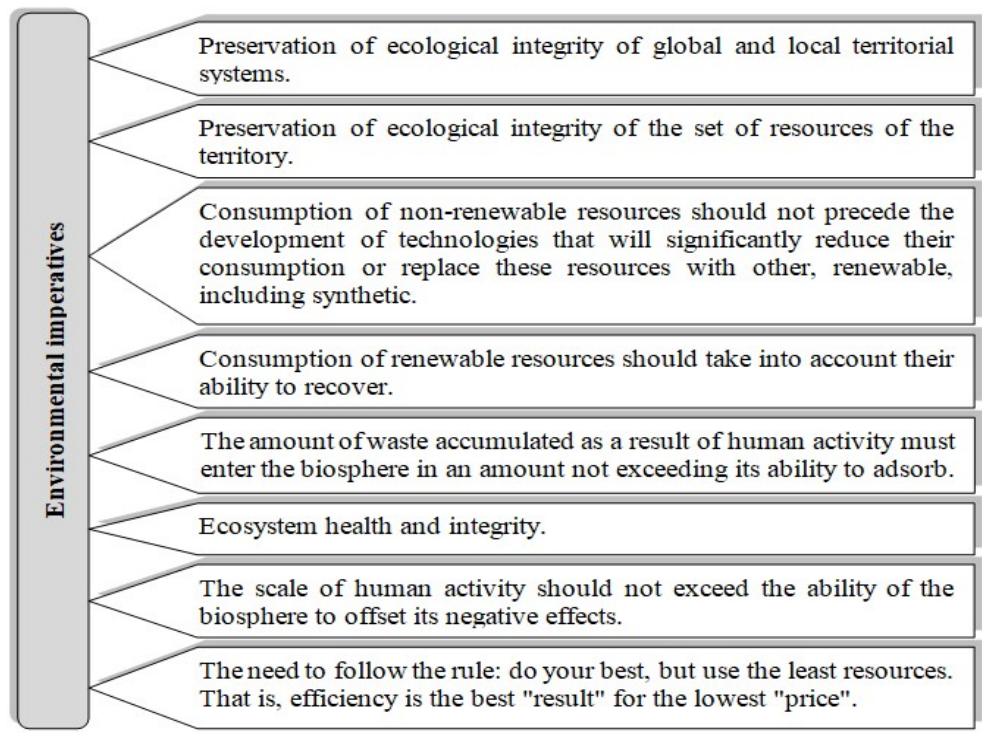

Fig. 5. Environmental imperatives for Ukraine.

Source: formed by the authors on the basis [16]

The main result of the application of the ecological and economic mechanism is the determination of strategic priorities of sustainable development in a particular country, in our case, in Ukraine. Based on the concept of sustainable development, a set of defined environmental imperatives and the Strategy for Sustainable Development of Ukraine until 2030, the authors formed a system of national strategic priorities (Fig. 6). 


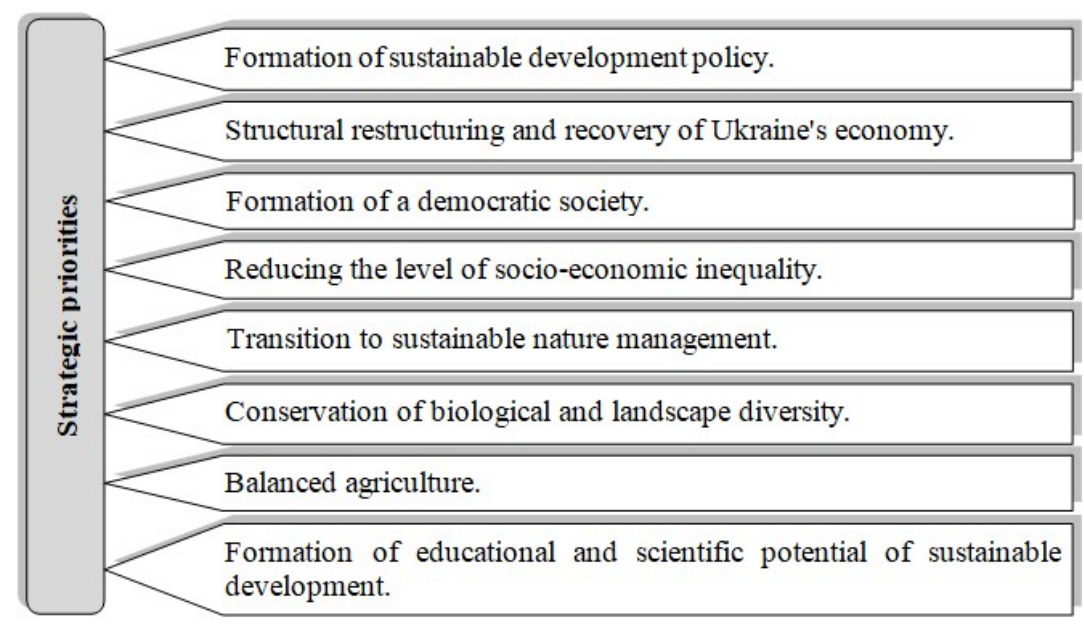

Fig. 6. System of the National strategic priorities of sustainable development for Ukraine.

Source: formed by the authors on the basis $[10,17]$

Each priority is a strategic vector for the development of the national economy, requires more detail and concrete action directly at each level - enterprises, industries, regions and the country as a whole.

\section{Conclusions}

The system of national priorities determines the strategic vector of society development and is implemented in the field of environmental imperatives that regulate anthropogenic activities and affect changes in the natural environment.

For its effective formation it is expedient to use the ecological and economic mechanism offered by authors which provides a rational choice of system of national priorities in the conditions of sustainable development taking into account ecological imperatives.

Further research of the authors is aimed at improving the proposed mechanism, detailing the system of national priorities in terms of levels of management and the formation of a comprehensive system of indicators for assessing the sustainable development of the country.

\section{References}

1. Bilgaev, A., Dong, S., Li, F., Cheng, H., Tulohonov, A., Sadykova, E., \& Mikheeva, A. (2021). Baikal Region (Russia) Development Prospects Based on the Green Economy Principles. Sustainability, 13(1), 157. https://doi.org/10.3390/su13010157

2. Zhang, L., Mu, R., Hu, Sh., Zhang, Q., \& Wang, S. (2021). Impacts of Manufacturing Specialized and Diversified Agglomeration on the Eco-Innovation Efficiency - A Nonlinear Test from Dynamic Perspective. Sustainability, 13(7), 3809. https://doi.org/10.3390/su13073809

3. Dudek, M., \& Wrzaszcz, W. (2020). On the Way to Eco-Innovations in Agriculture: Concepts, Implementation and Effects at National and Local Level. The Case of Poland. Sustainability, 12(12), 4839. https://doi.org/10.3390/su12124839 
4. Trofymova, V.V. (2010). Kontseptsiya staloho rozvytku yak osnova postindustrialnykh modelei rozvytku. Investment: Practice and Experience, 8, 33-37.

5. Kharazishvili, Yu.M. (2019). Systemna bezpeka staloho rozvytku: instrumentarii otsinky, rezervy ta stratehichni stsenarii realizatsii. NAN Ukrainy, Institute of Industrial Economics.

6. United Nations publication. (1993). Report of the United Nations conference on Environment and Development.

7. University for Peace. (2000). Earth Charter International. https://earthcharter.org/readthe-earth-charter/

8. United Nations General Assembly Resolution 37/7. (1982). World Charter for Nature.

9. Verhovna Rada of Ukraine. (2019). Pro Tsili staloho rozvytku Ukrainy na period do $2030 \mathrm{roku}$. https://zakon.rada.gov.ua/laws/show/722/2019?lang=en\#Text

10. UNDP in Ukraine. (2017). Sustainable Development Strategy for Ukraine by 2030.

11. Fedorova, N. (2015). The Role of science in the formation of models of sustainable development of the national economy, Vis-k SumDU, E, 1, 16-29.

12. Eurostat. (2020). SDGs\&me. https://ec.europa.eu/eurostat

13. MinfinMedia. (2021). Indscators. https://index.minfin.com.ua/

14. State Statistics Service of Ukraine. (2019). Statystychnyi shchorichnyk Ukrainy za 2018 rik. TOV «BUK-DRUK». https://ukrstat.org/en

15. State Statistics Service of Ukraine. (2019). Statystychnyi shchorichnyk Ukrainy za 2016 rik. https://ukrstat.org/en

16. Shpylova, Yu.B., \& Ilina, M.V. (2017). The meaning of the environmental imperative for the formation of reference points of a society's sustainable development. International Humanitarian University Herald. Economics and Management, 24(1), 811.

17. Sd4ua. (2021). Stalyi rozvytok dlia Ukrainy. Priorytety. https://sd4ua.org/priorytety/ 